\title{
ПРИНЦИП КЕРІВНИЦТВА ТА ЕТИКА «ВІДКРИТОГО СУСПІЛЬСТВА»
}

\begin{abstract}
А.І. Абдула
Анотація. «Відкрите суспільство» К. Поппера - не лише суто абстрактний конструкт, це також і система цінностей та ідеалів сучасної європейської цивілізації, таких як - свобода, індивідуалізм, гуманізм, демократія. Однак підгрунтя цієї системи, зв'язок між її елементами, взаємовідношення з сучасною політикою, перспективи реалізації та багато інших значущих тем й дотепер залишаються дискусійними. Автор аналізуе один із основоположних принципів «відкритого суспільства» - принцип керівництва та намагається з'ясувати, в якій мірі вирішення проблеми керівництва пов'язане з вимогами морального контролю. Обгрунтовується, що пошук відповіді на питання: «Хто не повинен керувати державою?» є стратегічною задачею «відкритого суспільства», пов'язаною із захистом його цінностей.
\end{abstract}

Ключові слова: відкрите суспільство, демократія, принцип керівництва, легітимність, демократичні цінності.

\section{Principle of LeAdership AND ETHICS OF «OPEN SOCIETY»}

\begin{abstract}
K. Popper's «Open Society» is not only an abstract construct, but also a system of values and ideals of modern European civilization, such as freedom, individualism, humanism, democracy. However, the foundation of this system, the link between its elements, the relationship with modern politics, the prospects for implementation and many other important topics remain problematic to this day. The author analyzes one of the fundamental principles of «open society» - the principle of leadership and tries to demonstrate, that the answer to the question: «Who shall rule the state?» is important in at least two aspects. Firstly, this question can be reformulated in the spirit of fallibilism as the question: «Who shall not rule the state?». Secondly, the search for an answer to this question can be considered as a strategic problem of an «open society» related to the protection of its values.
\end{abstract}

Keywords: open society, democracy, principle of leadership, legitimacy, democratic values. 
Філософська наука i, у зв'язку з нею, науки історична, політична, соціологічна в межах своїх завдань мають природну спрямованість на теоретичне дослідження та окреслення границь існування певних духовних утворень, культурних типів, цивілізаційних форм. Особливий інтерес при цьому викликає сучасний етап історичного розвитку, який не лише розглядається у світлі філософської реконструкції історичного процесу, але й, у залежності від обраної методології, зіставляється з певними ідеалізованими типами чи аналітичними моделями. Цей етап, у, мабуть, найбільш розповсюдженому техніко-технологічному ракурci, прийнято характеризувати як постіндустріальну чи інформаційну еру [1]. Однак зламний момент, характерний для субстанціювання суспільства «сучасного типу», може бути визначений і в інших, не менш важливих аспектах, зокрема, як досягнення врівноваження «старої», «індустріальної», «капіталістичної» системи розвинутими демократичними інституціями, становлення нових форм стійкої, «зрілої» демократії, виявлення її змісту тощо (див., напр.: [9]). Одним зі способів осмислення зазначеної культурно-цивілізаційної трансформації у руслі політичної філософії є побудова такої теоретичної моделі нового суспільства, яка б не лише враховувала зазначені особливості реальних суспільно-історичних перетворень, але й, перш за все, надавала їм філософське обгрунтування. Спробу створити таку модель сучасного демократичного суспільства, окреслити його фундаментальні принципи та засади функціонування здійснив відомий британський філософ Карл Поппер [12].

У своїй основоположній соціально-філософській праці «Відкрите суспільство та його вороги» [5], та й загалом у дослідженнях в межах проблемного поля суспільних наук, К. Поппер звертається до низки соціально-філософських проблем (критики історицизму та тоталітаризму, сутності ліберальної демократії, методології соціальних перетворень, соціальної справедливості, співвідношення раціональності та моралі тощо), розглядаючи їх у контексті розробленої ним парадигми «відкритого суспільства». Одним із ключових компонентів цієї моделі, навколо якого в значній мірі й будується попперівська концепція, є «вільна від парадоксів» теорія демократичного правління $[5$, c. 144]. Зазначену теорію можна віднести до «причинних основ» розробленої Поппером критико-раціоналістичної методології у її соціальнофілософському аспекті [4, с. 52].

Не зважаючи на значний проміжок часу, який минув з моменту написання «Відкритого суспільства», запропонована К. Поппером модель демократії зберігає актуальність не лише у площині суто теоре- 
тичних досліджень, але й у зв'язку з реальними політичними подіями. Зокрема, авторитетне британське видання ліберального спрямування «The Economist» двічі зверталось до попперівської публікації, в якій викладені засади його теорії: спочатку у 1988 р. у зв'язку з питаннями переходу до двопартійної системи, а пізніше - у контексті виборів президента США у 2016 р. [12]. Привертає увагу, що у передмові до зазначеної публікації підкреслюється суттєва відмінність між попперівською моделлю демократії та традиційними уявленнями про неї, як про «правління народу». На специфіку цієї моделі звертає увагу канадський дослідник Фред Ейдлін, який зазначає, що К. Поппер хоча i постає як активний захисник демократії (не лише на етичних засадах, але й на засадах її ефективності), його погляди відрізняються від традиційних уявлень, зокрема, розробників американської конституції [8, p. 69]. Підкреслює відмінності між традиційними формами демократичних теорій та попперівською теорію також австралійський філософ Джефрі Стокс, зауважуючи, що остання пропонує більш субстантивні цінності, оскільки вимагає від держави дій з усунення «конкретного зла» [13, p. 228].

Враховуючи той значний інтерес, який продовжує викликати загалом «відкрите суспільство», та зокрема, проблема його демократичного підгрунтя (у тому числі, у зв'язку з політичними процесами у Європейському Союзі [11], [10]), на наш погляд, було б доречним ще раз, звернувшись до цієї моделі, зосередити увагу, насамперед, на питаннях, пов'язаних з обгрунтуванням принципів демократичного керівництва, у тому числі, в їх етичному вимірі.

Узагальнений образ попперівської теорії демократії, за Д. Стоксом, може бути розглянутий за трьома основними напрямками. По-перше, демократія розглядається у відношенні не-насильництва та інтелектуального прогресу. По-друге, в питаннях з'ясування її природи та цілей. Тут йдеться про те, щоб замість відповіді на питання: «Хто має правити державою?» слід шукати відповідь на питання: «Як зорганізувати політичні інститути, щоб уникнути шкоди від некомпетентних чи поганих правителів?», а також, розмірковувати над тим, в який спосіб позбутися таких правителів не-насильницьким шляхом [13, p. 228]. Третій компонент стосується проблеми функціонування демократії, питань соціальної та економічної політики, шляхів захисту демократії [там само]. Хоча нас буде цікавити переважно другий аспект, вочевидь, всі інші складові є необхідними щодо формування цілісної моделі.

Тлом, на якому розгортається попперівська аргументація у «Відкритому суспільстві», як відомо, виступає критика «історицистських» 
філософських систем, перш за все, Платона, Гегеля та Маркса [5]. Тому не дивно, що одним із вихідних пунктів аналізу «принципу керівництва» є питання, яке, на думку Поппера, відіграє провідну роль в політичній теорії Платона, а саме проблема: «Хто правитиме державою?» [5, с. 139-140]. Однак, у даному випадку критика торкається не лише платонівської відповіді на нього, але й самого питання, яке під цим кутом зору якщо не набуває статусу псевдопроблеми, то стає принаймні другорядним. Більш того, пошук відповіді на подібні питання, на думку Поппера, створює небезпечну ілюзію того, що ключові проблеми політичної філософії (у вченні Платона, та не лише у нього) вже розв'язано, причому, головним чином, в етичній площині [5, c. 140]. Зазначена небезпека також полягає й у тому, що зорієнтовуючи політичну систему на пошук «найкращих» чи «обраних» правителів, всупереч демократичним настановам, нівелюються можливості тих, кого визнано невідповідними певним моральним, інтелектуальним чи навіть расовим або класовим критеріям [там само]. Виявляється, що загалом подібні риси є характерними для «закритого», недемократичного, тоталітарного суспільства, а в даному випадку - для «ідеальної держави» Платона. У той же час, демократія для Поппера є єдиним етично виправданим типом політичного режиму, оскільки, «гуманістична теорія справедливості» передбачає егалітаризм, iндивідуалізм, а також те, що держава існує для громадян і захисту їхньої свободи [8, p. 69]. Тому принцип керівництва у «відкритому суспільстві» (прототипи якого можна знайти також у Давній Греції) замість етичних фільтрів, які стосувалися би претендентів на владу, спирається на настанову не-насильницького усунення від влади «поганих», «некомпетентних» чи навіть «несправедливих» правителів [5, с. 140]. Подібне розуміння демократії на противагу уявленню про неї як про «правління народу» чи «правління більшості», згідно Поппера, дозволяє уникнути так званого «парадоксу демократії, коли народ чи «більшість» можуть цілком добровільно обрати тирана [5, с. 141-142]. Таким чином, демократія постає як спосіб інституційного контролю над владою, який унеможливлюе тиранію [5, с. 145].

Аналізуючи запропоновану Поппером концепцію, Ф. Ейдлін звертає увагу на те, що такі, на перший погляд, спрощені та, водночас, нетрадиційні визначення (демократії чи тиранії), насправді залишаються в значній мірі проблематичними. Ця проблематичність, на думку Ейдліна, пов'язана у тому числі з ігноруванням чи запереченням Поппером традиційних тем (таких як, наприклад, проблема передачі влади у правильні руки, або проблема суверенітету влади), що у свою 
чергу залишає невирішеними низку важливих проблем, серед яких: необхідність відмови від ідеалу народовладдя, проблема легітимності влади, ігнорування емоційних (нераціональних) аспектів політики, можливість безкровної передачі влади недемократичними режимами та інші питання [8, p. 75-81].

Ці зауваження цікавитимуть нас, перш за все, з точки зору морального аспекту функціонування демократії, але, водночас, важливим видається розкрити і той зв'язок, який існує між моральною та формальною (раціональною) складовою цього процесу.

Необхідність відмови від ідеалу (безпосереднього) народовладдя, навіть у контексті захисту демократії як етично виправданої та раціонально організованої системи, як зазначає Ф. Ейдлін, протиставляється уявленню тих політичних мислителів та активістів, які вважають, що керувати має саме народ [8, p.75]. Адже навіть якщо емпірично встановлено, що люди насправді не керують державою, то це не означає, що вони не повинні керувати [там само]. Якщо ж влада не розглядається у якості «правління народу», тобто, як підкреслює Поппер: «Хоча народ і може впливати на вчинки своїх правителів, загрожуючи повалити їх, він ніколи не здійснював самоуправління в якомусь конкретному, практичному розумінні» [12, с. 145], то це породжує питання легітимності такої влади. Однак К. Поппер вважає, що принцип легітимності, який історично вже вичерпав себе, з точки зору перспектив розбудови відкритого суспільства та демократії, $є$ хибним та шкідливим [12]. На думку Ф. Ейдліна, Поппер ототожнює легітимність з догматичним дотриманням абстрактного морального принципу, який обгрунтовує здійснення безконтрольного суверенітету $[8$, p. 78]. У зв'язку з цим, з певною долею іронії можна було б припустити, що під запропоноване Поппером розуміння демократії підпадає (а, можливо, якнайкраще його репрезентує) антична традиція (орієнтовно V ст. до н.е.) обирати владу за допомогою жеребу. При цьому дійсно не так важливо, «хто саме буде керувати», адже реалізується спосіб мирного, безкровного переобрання влади та інституційного контролю. Якщо ж заперечити, що у даному контексті йдеться про «волю богів», а не «волю людей», то «воля людей», як і «влада більшості», завжди видається чимось непевним, оскільки може бути спрямована на «обрання тирана» чи заперечення демократичних інституцій (не говорячи вже про наявну «волю до влади» чи про те, що незважаючи на всі заперечення все ж таки буття в значній мірі визначає свідомість). Загалом, акцент на інституційній сутності демократії виглядає цілком природно, адже відображує не лише ставлення Поппера до проблеми 
демократичної легітимності, але і його негативне ставлення до емоційних та ірраціональних аспектів політики в цілому [там само]. Останнє може бути виявлено, зокрема у вимозі обмеження державою вільного ринку, заради реалізації його «єдиної раціональної мети»- «задоволення вимог споживача» [6, с. 401].

Однак емоційна складова має не лише негативне забарвлення, адже може йтися, наприклад, про «пристрасть науковця» чи «палкого захисника демократії [8, p. 78]. Тому є сенс згадати класичну інтерпретацію цієї проблеми, запропоновану в працях М. Вебера, який обгрунтовує думку про те, що формальна демократія все-таки має недостатню легітимність [2, с.636-637] і повинна бути доповнена реальним етичним зразком, уособленням та носієм моральних цінностей, моральним авторитетом [3, с. 90-91]. Водночас деяким окремим суспільствам, а можливо і загалом сучасному суспільству, за межами релігійного світогляду не вистачає твердої основи, щоб вийти зі стану морального релятивізму, з точки зору якого й, власне, демократична система, як цінність, також стає відносною. Цей, якщо так можна висловитись, недолік демократії, робить в очах багатьох більш привабливими авторитарні режими, особливо ті, в яких лідер ніби уособлює уявні чи реальні моральні чесноти. Тому, на нашу думку, ідея доповнити формальну демократію певним моральним взірцем не виглядає безпідставною.

Цікаво, що, здавалося б у супереч заявленій настанові, Поппер не прагне повністю уникнути «позитивного» етичного підтексту, підкреслюючи, що незважаючи на те, що ми, насамперед, повинні готуватися до найгіршого, ми все одно повинні прагнути найкращого (уряду) [5, с. 142]. У такому випадку виникає підозра, що все-таки існує певний спосіб попередньо визначати, що уряд нас буде влаштовувати, або, як мінімум, що уряд некомпетентний, несправедливий чи навіть аморальний. Відповідаючи на запитання, чи не означає «некомпетентний» у даному випадку як раз і «аморальний», можна припустити, що аморальним такий уряд (правитель) буде вважатись, якщо сприятиме руйнації демократичної системи, відмовившись від «критичного розуму», у той час як компетентність може означати «ефективність» чи здатність виконувати свої обов'язки. Якщо ж зосередитись не на тому, наскільки влада компетентна, а на тому, що їі можна безкровно змінити, а також контролювати (в межах моралі), видається, що може існувати певна система попереднього «морального оцінювання» типу урядів, які потенційно загрожують демократичним засадам, ще до їх обрання. Тобто замість того, щоб шукати «найкращого» правителя, ми могли б принаймні зосередитись на попереднъому вияві «найгіршого». 
Хоча, як наполягає Поппер: «У сфері політичних проблем різниці між особами та інститутами відповідає різниця між щоденними і стратегічними проблемами» $[5$, с. 147$]$, прихід до влади нацистів чи релігійних фанатиків може стати глобальною проблемою, а унеможливлення цього можна було б вважати одним зі стратегічних завдань.

$\mathrm{У}$ даному випадку як раз доречно використовувати етичний критерій, який вимагає жорстко реагувати на загрозу індивідуальній свободі, порушенню принципу рівності громадян перед законом тощо. Особливо хотілося б зупинитися на індивідуалізмі, який у поєднанні з альтруїзмом, на думку Поппера, є фундаментом європейської цивілізації [5, с. 142]. Йдеться не лише про сучасні політичні доктрини, але й про християнські цінності («полюби ближнього свого, а не своє плем'я»), практичну доктрину Канта («завжди визнавайте кінцевою метою людську особистість і не використовуйте її як засіб для досягнення своїх цілей») та інші доктрини, що виникли з європейської цивілізації та стимулювали їі [5, с. 143]. Однак, заклики, спрямовані проти демократичних інституцій та ідеалів, як це не дивно, $є$ і донині явною чи завуальованою складовою передвиборчих програм певних політичних сил у країнах, які намагаються позиціонувати себе як демократичні. Заперечення індивідуалізму та свободи, як правило, відбувається за рахунок ствердження трибалізму та холістичних уявлень щодо релігії, держави, народу та нації. Привертають увагу й «помірковані» зауваження сучасних філософів (не лише постмарксистського спрямування) щодо утопічності «відкритого суспільства», небезпечності задекларованої відкритості, яка ніби призводить до його саморуйнації (на прикладі Європейського Союзу), а, отже, необхідності звернення до національної ідеї та традицій, як підгрунтя «емпіричної» відкритості [11]. Зокрема, Ентоні O’Xеа, характеризуючи «негативний утилітаризм» Поппера, стверджує, що усунення «страждань та несправедливості» в «ідеалізованому» «відкритому суспільстві» передбачає апелювання до певного спільного морального уявлення, якого за умови тотальної індивідуалізації просто неможливо досягти [11, р. 208]. Небезпека ж ніби полягає у тому, що надмірна «емпірична» «відкритість» (наприклад, до міграції) призводить до переструктурування суспільства таким чином, що значна частина населення перестає поділяти його цінності або не може його захистити. Вихід із цього становища дослідник вбачає у тому, щоб усупереч кантівській настанові апелювати до ірраціональних чинників, національної свідомості чи традицій $[11$, p. 211-215]. До такого типу заперечень, на наш погляд, треба ставитись дуже обережно, оскільки схожі аргументи загалом використовуються 
щодо критики демократії чи лібералізму, у тому сенсі, що останні «утопічні», «реально не працюють», є «небезпечною оманою» тощо, тобто потребують «принципово іншої» альтернативи.

У той же час, принцип морального контролю міг би доповнити думку щодо ненасильницької передачі влади, як ключової ознаки демократії, оскільки сучасні авторитарні режими, ототожнюючи себе 3 державою, змогли досягти такого рівня політичного контролю, який забезпечує ненасильницьку передачу влади, заміну одних урядів іншими та навіть «вибори» в межах існуючої системи.

Вочевидь, «відкрите суспільство» не вичерпується розглянутими вище аспектами. Ця модель набагато більш глибока, ніж може виявитися на перший погляд, адже за їі, здавалося б, простими формулюваннями вимальовуються спроби розв'язати важливі, якщо не фундаментальні проблеми сучасної політичної філософії. Недаремно К. Поппер, намагаючись ввести поняття «соціальної інженерії», «історицизму», «гуманістичної теорії справедливості», «протекціонізму», апелює до парадоксів демократії, свободи, вільного ринку (деякі дослідники розмірковують також над парадоксом «відкритості» [11]). Тематика, якої ми торкнулися у нашій роботі, тісно переплетена з зазначеними поняттями, оскільки стосується фундаментального принципу політичної системи «відкритого суспільства» - «принципу керівництва», його не лише раціонального, але й етичного підгрунтя. На наш погляд, у сучасному (відкритому) суспільстві дійсно відчувається недолік позитивного змісту демократії не лише на теоретичному, але й на емпіричному рівнях. Значна кількість політичних режимів, і не лише в перехідних суспільствах, функціонують «на межі» демократії, яку їм не дають перетнути як раз ті «противаги», які захищає Поппер. Однак, нам також видається важливою й спроба закцентувати увагу на перспективах не лише «захисту від найгіршого», а й на можливостях раціонального та морального обрання принаймні «не найгіршого» уряду.

\section{Література}

[1] Белл Д. Грядущее постиндустриальное общество. Опыт социального прогнозирования. - Москва: Academia, 1999.

[2] Вебер M. Избранные произведения [пер. с нем., общ. ред. Ю.Н. Давыдова]. - Москва : Прогресс, 1990. 
[3] Гайденко П.П. История и рациональность: Социология М. Вебера и веберовский ренессанс / П.П. Гайденко, Ю.Н. Давыдов. - Москва : Политиздат, 1991.

[4] Качоха B.K. Поппер: альтернатива обществу будущего // Вопросы философии. - 2002. - № 6. - С. 48-59.

[5] Поппер K. Відкрите суспільство та його вороги: в 2 т. [пер. $з$ англ. О. Коваленко]. - Т. 1: У полоні Платонових чар: Гегель, Маркс та послідовники. - Київ : Основи, 1994.

[6] Попnер K. Відкрите суспільство та його вороги: в 2 т. [пер. 3 англ. О. Буценко]. - Т. 2: Спалах пророцтва: Гегель, Маркс та послідовники. - Київ : Основи, 1994.

[7] Eidlin F. Popper and Democratic Theory // Studies in political thought. - 1993. - Vol. II. - No. 1. - P. 69-84.

[8] Merkel W. Is capitalism compatible with democracy? / Wolfgang Merkel [Electronic resource] // Zeitschrift für vergleichende Politikwissenschaft, 2014. - Mode of access: https://projects.iq.harvard.edu/files/mobilized_contention/files/merkel__is_capitalism_compatible_with_democracy.pdf

[9] Miloslav B. Open Society and the European Union // Rethinking Popper. - Edited by Zuzana Parusniková, Robert S. Cohen. - Springer Science + Business Media B.V., 2009. - P. 237-245.

[10] O'Hear A. Popperian Individualism Today // Rethinking Popper. Edited by Zuzana Parusniková, Robert S. Cohen. - Springer Science + Business Media B.V., 2009. - P. 205-217.

[11] Popper K. From the archives: the open society and its enemies revisited [Electronic resource] // The Economist, 2016. Mode of access: https://www.economist.com/democracy-inamerica/2016/01/31/from-the-archives-the-open-society-and-itsenemies-revisited

[12] Stokes G. Karl Popper's Revisionist/Realist Theory of Democracy // Karl Popper: A Centenary Assessment. - Vol. I: Life and Times, and Values in a World of Facts. - Edited by Ian Jarvie, Karl Milford, David Miller. - New York : Routledge, 2019. - P. 217-230. 


\section{References}

[1] Bell D. Gryadushee postindustrialnoe obshestvo. Opyt socialnogo prognozirovaniya. - Moskva: Academia, 1999.

[2] Veber M. Izbrannye proizvedeniya [per. s nem., obsh. red. Yu.N. Davydova]. - Moskva : Progress, 1990.

[3] Gajdenko P.P. Istoriya i racionalnost: Sociologiya M. Vebera i veberovskij renessans / P.P. Gajdenko, Yu.N. Davydov. - Moskva: Politizdat, 1991.

[4] Kachoha V.K. Popper: alternativa obshestvu budushego // Voprosy filosofii. - 2002. - №6. - S. 48-59.

[5] Popper K. Vidkrite suspilstvo ta jogo vorogi: v 2 t. [per. z angl. O. Kovalenko]. - T. 1: U poloni Platonovih char: Gegel, Marks ta poslidovniki. - Kiyiv: Osnovi, 1994.

[6] Popper K. Vidkrite suspilstvo ta jogo vorogi: v 2 t. [per. z angl. O. Bucenko]. - T. 2: Spalah proroctva: Gegel, Marks ta poslidovniki. - Kiyiv : Osnovi, 1994.

[7] Eidlin F. Popper and Democratic Theory // Studies in political thought. - 1993. - Vol. II. - No. 1. - P. 69-84.

[8] Eidlin F. Popper and Democratic Theory // Studies in political thought. - 1993. - Vol. II. - No. 1. - P. 69-84.

[9] Merkel W. Is capitalism compatible with democracy? / Wolfgang Merkel [Electronic resource] // Zeitschrift für vergleichende Politikwissenschaft, 2014. - Mode of access: https://projects.iq.harvard.edu/files/mobilized_contention/files/merkel__is_capitalism_compatible_with_democracy.pdf

[10] Miloslav B. Open Society and the European Union // Rethinking Popper. - Edited by Zuzana Parusniková, Robert S. Cohen. - Springer Science + Business Media B.V., 2009. - P. 237-245.

[11] O'Hear A. Popperian Individualism Today // Rethinking Popper. Edited by Zuzana Parusniková, Robert S. Cohen. - Springer Science + Business Media B.V., 2009. - P. 205-217. 
[12] Popper K. From the archives: the open society and its enemies revisited [Electronic resource] // The Economist, 2016. Mode of access: https://www.economist.com/democracy-inamerica/2016/01/31/from-the-archives-the-open-society-and-itsenemies-revisited

[13] Stokes G. Karl Popper's Revisionist/Realist Theory of Democracy // Karl Popper: A Centenary Assessment. - Vol. I: Life and Times, and Values in a World of Facts. - Edited by Ian Jarvie, Karl Milford, David Miller. - New York: Routledge, 2019. - P. 217-230.

Надійшла до редакції 12 серпня 2019 р.

\section{Абдула Андрій Іванович}

Кафедра філософії

Криворізький державний педагогічний університет

просп. Гагаріна, 54

м. Кривий Ріг

50086

\section{Abdula Andrii}

Department of Philosophy

Kryvyi Rih State Pedagogical University

Gagarina ave., 54

Kryvyi Rih

50086

iD https://orcid.org/0000-0001-5484-1639

@ standrewne2@gmail.com

doi) 10.31812 /apd.v0i20.2597 